\title{
Role of ECA's (Extra Curricular Activities) in Personality Development
}

\section{${ }^{1}$ Muhammad Ismail*, ${ }^{2}$ Muhammad Nadeem, ${ }^{3}$ Malik Hashim Hussain Thind, ${ }^{4}$ Muhammad Aamir Shaheen, ${ }^{5}$ Muhammad Shahid, ${ }^{6}$ Rashid Ahmad, ${ }^{7}$ Usman Mehmood}

${ }^{1}$ MS/M.Phil: Marketing Management, Lecturer: Commerce \& Management Sciences Department, NCBA\&E-Lahore, Layyah Campus. Layyah Pakistan

${ }^{2}$ Faculty of Business Management B.Z University, Multan

${ }^{3}$ MS Business Administration, M.Phil Commerce, Campus Director: NCBA\&E-Lahore, Layyah Campus.

${ }^{4}$ MS Business Administration, Deputy Campus Director: NCBA\&E-Layyah Campus

${ }^{5}$ MS Scholar Business Administration, Institute of Southern Punjab. Multan

${ }^{6}$ Faculty of Economics NUML University, Multan, ${ }^{7}$ Ms scholar institute of southern punjab

\begin{abstract}
By following the entire categories of ECA's, our targeted respondents were university students. Our D.V was "Personality" and I.V's were "ECA's\& "Educational Performance" We've found that more participation in ECA's can make the students as a shining stars, build up their leadership qualities, make them future leaders and improve their sportsmanship. Our hypotheses also retrospective that Extracurricular Activities can develop the personality (Big Fives). Our targeted audience were university students (N=941) who belongs to different departments of five dissimilar universities, as well as Arid Agricultural University Rawalpindi, B.Z. University Multan, COMSATS IIT Vehari, GC University Faisalabad and NCBA\&E-Layyah campus. Most of the respondent were interested in the cricket, bivariate correlation and the Results of our research study are robust because (Significant level) Sig. (I-tailed) among D.V \& I.V were significant and strongly positive to each other. We've used the five point likert scale to check the personality traits and then analyzed the descriptive statistics, likewise regression coefficient, Pearson $(r), R^{2}$, ANOVA, Standard Deviation, Durbin-Watson and Residuals Statistics. Cronbach's Alpha was 0.8.
\end{abstract}

Keywords: ECA's, Personality, improvement, leadership, academic achievement.

\section{Chronological View of Eca's Involvement}

Usually the involvement in extracurricular activities (ECAs) produce the positive attitude, enhance the social and academic development among the students (Werner \& Smith, 1982; Andre \& Holland, 1987; Gordon, 1996; Young et al, Silliker \& Quirk, 1997). However this statement not always supported in empirically and theoretically, that schools were idealistic place only for academia purposes between the decade of 1950 to 1960 (Gholson, 1985).

Minor Extracurricular activities were part of the traditional schools that were directly link to curriculums (Marsh, 1992; Cairns \& Mahoney 1997). Student's athletic activities were disputed that it's wastage of time (Marsh, 1992; Camp, 1990; McNeal, 1998). But research from 1960 to 1970 retrospective that enrolment in ECAs make the students more civilize, cultural and social (Spady, 1970; Otto, 1976). In the decade of 1970 to 1980 advanced social and famous students became the role model \& leader (Gerber, 1996). Marsh emphasized it the zero sum model (students involved in activities have low interest \& time for study, so they'll suffer, because no pass and no play) (Gerber, 1996). Research from 1980 to 1990 formed qualitative \& empirical evidences for zero sum model that ECAs develops good social relations \& improve problem solving skills (Spady, 1970; Andre \& Holland, 1987; Marsh, 1991; Spreitzer \& Snyder, 1992; Fejgin, 1994; Gordon, 1995)

Now latest speculation has been acknowledged that participation in ECAs is extremely advantageous (Midgley, Eccles, 1990; Gerber, 1996; Rock \& Finn, 1997) now argument built on previous assumption that academic and social both factors are necessary to achieve the goal (Armentrout, 1979; Gholson, 1985; Marsh, 1992). Participation in activities elevates the academic concepts as well as other skills. It acknowledge in school/ university. Also improve the cultural \& social values and student's performance (ODonnel, 1992; Ford, 1995). 


\section{INTRODUCTION}

Any adolescent shouldn't be left behind from their life visions and achievements, American institutes are strongly emphasizing on extracurricular activities, (Lewis 2005). In this scientific revolution age human education considered as primary step to motivate the individuals. It's playing a fundamental role in human capital and with the help of it every student can link their opportunities properly (Battle $\&$ Lewis, 2002). It ensures the attainment of skills and knowledge that enhance the quality and productivity of their life. It also show the new ways of economics intensification and student's personality development (Farooq et al 2011)

Mostly teenagers of America, they participate in and outside the institute activities as well as dance, youth groups, athletic games, clubs, drams, scouts, theater, students council and sports etc, it determine that what type of personality they have? (Wilson, N.2009). These extracurricular activities are the integral part of the educational program. So the extracurricular activities have a legitimate relationship with the student's responsibilities, human needs, character, social linkages, talents, skills and solution of critical circumstances (Klesse \& D'Onofrio 2000)

Those students who don't participate in the activities at their educational phase, they face an inadequate and different perception at the recruitment time in corporate level, and then they advised to get any diploma for skills development for getting a job. Different surveys reports show that recruiters hire only those candidates who are on the top of their list that include leadership and interpersonal skills (Eberhardt et al 1997). Successfully emotional intelligence can be achieved in the real world via extracurricular activities that learned during the academic age at institutes (Rubin et al 2002)

Professional, career and occupation of any individual can be measure and develop during the academic time span at professional institutes (Hammer 2000) that focus on the student's extracurricular activities. These activities help out the students in socialization (Heckman \& Kautz 2013).

\section{OBJECTIVES OF THE STUDY}

The main objectives of the study were to:

3.1 Scrutinize the importance of ECAs

3.2 How ECAs revolutionize the attitude and personality?

3.3 Factors that play a vital role in personality development

\section{REVIEW OF LITERATURE}

Rubin, R. S et.al (2002) Success of any organization based on high intellects. University recruiters analyze the candidates who've emotional intelligent, well rounded and having interpersonal skills, try to examine the correlation flanked by interpersonal skills, leadership and development with ECA, and eventually analyzed that they've a momentous relationship. Darling, et.al (2005) Participation in ECAs (Extracurricular activities) and adolescent have a positive relationship, more involvement in ECAs build attitude to cope up confusion and adolescent. Those pupils who actively participate in ECSs are reported better as compare to others. Farooq, M. S et.al (2011) Multiple factors can influence on the student's performance in secondary level, as well as the high socioeconomic status \& parental literacy rate effect in the development of student's life. Wilson, N. (2009) Actively participant students in ECAs generally get advantages likewise superior test scores, educational attainments, outdoor \& leadership skills, better team work \& grads and better academic concepts, they quit drugs and absenteeism but ECA often cost the money.

Heckman \& Kautz (2013) Cognitive and the non-cognitive skills can be measured after participation in ECAs it stimulates personality qualities, preferences, motivations in school domains. Appreciation necessary to enhance the skills that invest in the school or university age, but it offered by the triumphant families. It'll be helpful in later life. Lewis, C. P. (2005) Proficiency in social skills \& educational psychology promote in the presence of extracurricular activities, among the 141 wellknow studies 41 meta analyses shows that adolescents \& children (student's) performance were considerably related to the pro-ECAs. Singh Annu \& Mishra Sunita (2005)120 respondents between 13-16 age, who've participated in 6 types of ECAs (Horse riding, Yoga, Viz, Music, Sports and Dance) these ECAs influenced the students in the development of social skills, good grades, regularity, self-concept, and degree completion. 
Soe, H. P. (2014) Newsletters and documents of Myanmar University are revealed that objective, mission statement and learning outcomes of LAP (Liberal Arts Program) which were designed; these were achieved with the help of participation and taking interest in ECAs. Kolchenko, K.,\& Kozlikovska, N. (2012) A sound balanced amalgamation of the learning, practice and systematic research can be possible with the help of only ECAs not in traditional way of education. Park, D. (2015) Potential ECAs can develop the language proficiency, emotional \& social wellbeing, fantastic academics interest and marvelous confidence among the pupils. Massoni, E. (2011) Future of students determined in their activities that they do at home after school before coming parentage. Wangai, M. M. (2012) combination of student's teachers \& parentage's talent can enhance the performance and talent of pupils by ECAs. Reva, A. (2012) foreign language can be learned with the help of ECAs in Russia \& Canada. Lisa Keenan (2015) Perspective of Psychology, economics and social sciences can be develop in labour market and career development's path designed in college ECAs. Pitts, S. E. (2008) Music with the help of extracurricular activities retrospective and evaluate the life engagement of teenage in British school. Bloomfield \& Barber (2010) Adolescents of Australian students and their positive \& negative aspects lucratively get rid off by extracurricular activities.

Fung \& Wong (1988) analyzed that Involvement in the extracurricular activities having a constructive relation with acceptance by class mates, academic performance, carrier development and student's personality in Hong Kong.

\section{RESEARCH Methodology}

Cross sectional data was used in this research study. Data was collected by survey from different five universities that were accredited from HEC Pakistan. We've used the both primary and secondary data. Primary data collected with the help of questionnaire from five universities. Secondary data was collected from books, research papers, internet and magazine journals etc.

\subsection{Selected Variables}

In this research study one Dependent Variable "Personality" (Extraversion, Agreeableness, Conscientiousness, Emotional stability v/s Neuroticism and Culture) and there are two Independent Variables (1- ECA's and 2- Educational Performance) we have shown these above variables in our conceptual framework.

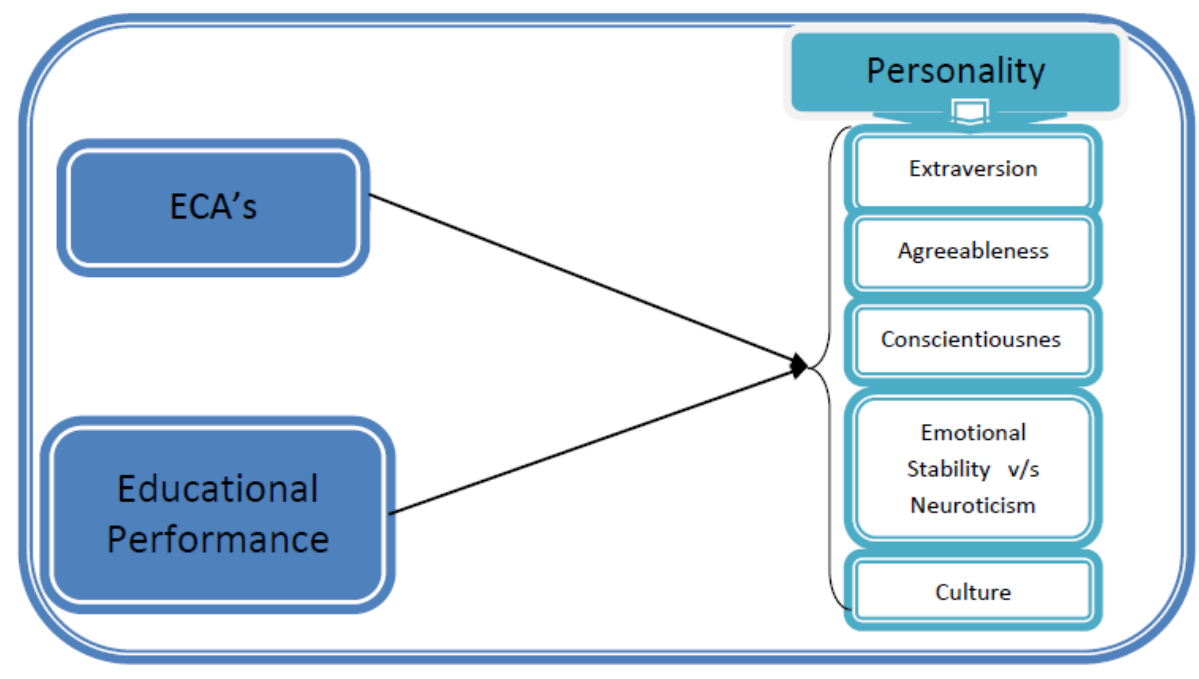

Figure1. Conceptual Model

This five factor arrangement personality model also called the "Five Bigs" it was replicated from Norman (1963), as well as Digman \& Borgatta (1964), and finally Chock Takemoto (1981) . Here Norman (1963) labeled the list of Personality into "Five Bigs" these are as follows.

(I) Extraversion or insurgency (assertive talkative, energetic)

(II) Agreeableness (cooperative, fine natured, , trustful)

(III) Conscientiousness (responsible, orderly, dependable)

(IV) Emotional Stability versus Neuroticism (cool \& calm, not easily upset, not neurotic)

(V) Culture (polished, intellectual, independent-minded) 
These above mentioned factors know as "Five Bigs" Goldberg (1981). It represents that each of these factors is enormously broad. So these "Five Bigs" structure not explores the entire personality difference, rather these "Five Bigs" represents the personality at a maximum broadest level. Each element or factor summarized the maximum number of distinctions, aspects and maximum characteristics of the personality.

\section{TYPES OF ECAS}

(Gabler \& Kaufman, 2004) sort out the ECAs into (13) thirteen categories.

1. Intramural team sport (football, hockey, baseball, soccer and basketball etc.)

2. Intramural individual sports (golf, cross - country, gymnastics and tennis)

3. Interscholastic team sports (football, hockey, baseball, soccer and basketball)

4. Interscholastic individual sports (golf, cross-country, gymnastics, tennis, track, wrestling and swimming etc.)

5. Orchestra, Chorus, Band and other music groups.

6. Musical, Drama club and School play.

7. Drill team, Cheerleading and Pompom.

8. Academic honour society, National Honour Society.

9. Pupil / Student's government.

10. Academic club (Debate, computer, foreign languages, philosophy club and art etc)

11. School yearbook, magazines, newspapers etc.

12. Hobby Clubs (Chess and photography etc).

13. Services Club (Key Club and American Field Service etc).

(Mahoney, 2000) explored that Indonesian institutes also carry out the six ECAs as well as

1. Scouting.

2. Marching Bands.

3. Religious Programs.

4. Sciences and philosophy (science club and debate etc)

5. Sports (Basket ball, badminton, volley ball, karate and soccer etc)

6. Arts (Class room decoration, chart making, classic dancing drawing etc.)

\section{Distinction OF RESEARCH STUdy}

Early research studies were based on, only Academic/educational subject wise performance (subject wise Mathematics, Science and English Marks) etc, but in this research we've highlighted that how personality can change with the help of ECA's (Extra Curricular Activities)

- Our targeted audience was the university level student.

- We have analyzed the impacts of ECAs on the personality development.

- Graduate and post graduate level students have a different thinking level as compared to adolescents and school childes.

\subsection{Research Questions}

Basically three questions will attempt to explore this research study.

1. In what ECA's students are choosing?

2. How many students participate in ECA's?

3. What is relationship flanked by ECA's and Personality Development?

4. How many times you've actively participated in ECA's (13 core types)? 
Role of ECA's (Extra Curricular Activities) in Personality Development

5. How University's Educational Performance related to the extracurricular activities?

6. How your Personality (Big Five) development was developed with the help of ECA's?

\subsection{Hypotheses}

$\mathbf{H}_{\mathbf{0}}$ : ECA's don't have a positive relationship flanked by ECA's \& Personality development.

$\mathbf{H}_{\mathbf{1}}$ : ECA's have a positive relationship flanked by ECA's \& Personality development.

\subsection{Method and Procedure}

This research study based on the cross sectional data. Our respondents were belonged to Universities. Questionnaire was used to collect data. Questionnaire based on the Demographic information, Academic information, extracurricular activities questions and finally Personality questions. Both Primary and Secondary data was used. Primary data collected from university surveys and secondary data from books, research papers, magazines, internet and other journals etc.

\section{DAta ANALYSIS AND INTERPRETATIONS}

Table. No. 1 Reliability Statistics

\begin{tabular}{|c|c|}
\hline Table. No.1 Reliability Statistics & \\
\hline Cronbach's Alpha & N of Items \\
\hline 0.8 & 59 \\
\hline
\end{tabular}

Cronbach's Alpha $(\dot{\alpha})$ results are 0.8 that shows the reliability of our research study questionnaire. (Nnnally, 1978) \& Fraekel \& Wllen (2003) said that Cronbach's Alpha ( $\dot{\alpha})$ never be less than 0.7. Consequently from above table, Cronbach's Alpha ( $\dot{\alpha})$ is > (greater than) 0.7. so it considered as tremendous and reliable results (Sekaran, 2003).

\section{DESCRIPTIVE STATISTICS}

\section{DEMOGRAPHIC INFORMATION}

Gender: In our research study there were $520(55.3 \%)$ male \& 421 (44.7\%) female student respondents respectively.

Age: Between 18-20 there were 220 (23.4\%), between 21-25 there were 581 (61.7\%), between 26-30 there were $91(9.7 \%)$ and above 30 years there were $49(5.2 \%)$.

\begin{tabular}{|c|c|c|c|c|c|}
\hline \multirow{2}{*}{\multicolumn{2}{|c|}{ Table No. 2}} & \multicolumn{4}{|c|}{ Classes Detail } \\
\hline & & Frequency & Percent & $\begin{array}{c}\text { Valid } \\
\text { Percent }\end{array}$ & $\begin{array}{c}\text { Cumulative } \\
\text { Percent }\end{array}$ \\
\hline \multirow{4}{*}{ : } & Bachelor & 282 & 30.0 & 30.0 & 30.0 \\
\hline & Master & 615 & 65.4 & 65.4 & 95.3 \\
\hline & M.Phil / Ph.D & 44 & 4.7 & 4.7 & 100.0 \\
\hline & Total & 941 & 100.0 & 100.0 & \\
\hline
\end{tabular}

Class vise there were $282(30 \%)$ students belongs to Bachelor classes, 615 (65.4\%) belongs to Master level classes and 44 (4.7\%) students belongs to M.Phil/Ph.D level classes.

\section{BELONGINGNESS OF THE RESPONDENTS}

\begin{tabular}{|c|c|c|c|c|c|}
\hline \multicolumn{2}{|c|}{ Table. No. 3 } & Students Belongingness from Universities \\
\hline \multicolumn{2}{|c|}{} & Frequency & Percent & $\begin{array}{c}\text { Valid } \\
\text { Percent }\end{array}$ & $\begin{array}{c}\text { Cumulative } \\
\text { Percent }\end{array}$ \\
\hline \multirow{4}{*}{$*$} & Arid Agricultural University. Rawalpindi & 191 & 20.3 & 20.3 & 20.3 \\
\cline { 2 - 6 } & B.Z. University. Multan & 183 & 19.4 & 19.4 & 39.7 \\
\cline { 2 - 6 } & COMSATS IIT. Vehari & 174 & 18.5 & 18.5 & 58.2 \\
\cline { 2 - 6 } & GC University. Faisalabad & 193 & 20.5 & 20.5 & 78.7 \\
\cline { 2 - 6 } & NCBA\&E-Lahore, Layyah Campus & 200 & 21.3 & 21.3 & 100.0 \\
\cline { 2 - 6 } & Total & $\mathbf{9 4 1}$ & $\mathbf{1 0 0 . 0}$ & $\mathbf{1 0 0 . 0}$ & \\
\cline { 2 - 6 } & \multicolumn{2}{|c|}{} & &
\end{tabular}

Our respondents were belongs to five different universities of Pakistan. We got the 191 (20.3\%) student's response from Arid Agricultural University Rawalpindi, 183 (19.4\%) students from B.Z. University Multan, 174 (18.5\%) student from COMSATS IIT Vehari Campus, 193 (20.5\%) from GC University Faisalabad and finally $200(21.3 \%)$ student's response from NCBA\&E-Lahore, Layyah Campus. 
Muhammad Ismail et al.

\begin{tabular}{|c|c|c|c|c|c|}
\hline \multicolumn{2}{|r|}{ Table No. 4} & \multicolumn{4}{|c|}{ Student's Specialization } \\
\hline & & Frequency & Percent & Valid Percent & $\begin{array}{l}\text { Cumulative } \\
\text { Percent }\end{array}$ \\
\hline \multirow{7}{*}{$\frac{\pi}{7}$} & Computer Sciences & 364 & 38.7 & 38.7 & 38.7 \\
\hline & Commerce / Business Administration & 322 & 34.2 & 34.2 & 72.9 \\
\hline & Natural Sciences & 174 & 18.5 & 18.5 & 91.4 \\
\hline & Engineering \& Technology & 60 & 6.4 & 6.4 & 97.8 \\
\hline & Arts & 12 & 1.3 & 1.3 & 99.0 \\
\hline & Others & 9 & 1.0 & 1.0 & 100.0 \\
\hline & Total & 941 & $\mathbf{1 0 0 . 0}$ & $\mathbf{1 0 0 . 0}$ & \\
\hline
\end{tabular}

Student's belongs to different discipline. 364 students from Computer Sciences, 322 students from Commerce/Business Administration, 174 from Natural Sciences, 60 from Engineering \& Technology, 12 from Arts group and finally 9 from Other Departments.

\begin{tabular}{|c|c|c|c|c|c|}
\hline \multicolumn{3}{|c|}{ Table No. 5} & \multicolumn{3}{|c|}{ Game Types } \\
\hline & & Frequency & Percent & Valid Percent & Cumulative Percent \\
\hline \multirow{12}{*}{$\frac{\pi}{\frac{\pi}{\pi}}$} & Cricket & 352 & 37.4 & 37.4 & 37.4 \\
\hline & Hockey & 66 & 7.0 & 7.0 & 44.4 \\
\hline & Bed Minton & 146 & 15.5 & 15.5 & 59.9 \\
\hline & Tennis & 16 & 1.7 & 1.7 & 61.6 \\
\hline & Table Tennis & 12 & 1.3 & 1.3 & 62.9 \\
\hline & Football & 56 & 6.0 & 6.0 & 68.9 \\
\hline & Snooker & 6 & .6 & .6 & 69.5 \\
\hline & Wrestling & 14 & 1.5 & 1.5 & 71.0 \\
\hline & Tug War & 3 & .3 & .3 & 71.3 \\
\hline & Racing & 56 & 6.0 & 6.0 & 77.3 \\
\hline & Other Minor Games & 214 & 22.7 & 22.7 & 100.0 \\
\hline & Total & 941 & 100.0 & 100.0 & \\
\hline
\end{tabular}

We've analyzed one more thing from this research that most of the students whether male or female. They've keen interest in the Cricket, There portion was $352(37.4 \%)$ students. It's a larger portion of our respondents. Then $214(22.7 \%)$ students were interested in other minor games. At the third number was Bed Minton 146 (15.5\%). So we can say that cricket is the most interested game of the students. So Government of Pakistan should contemplate on the National game of Pakistan.

\section{DESCRIPTIVE STATISTICS}

\begin{tabular}{|c|c|c|c|}
\hline \multicolumn{2}{|c|}{ Table No. 6 } & \multicolumn{3}{c|}{ Descriptive Statistics } \\
\hline & Mean & Std. Deviation & N \\
\hline Personality & 103.29 & 11.249 & 941 \\
\hline Extracurricular Activities & 23.96 & 12.472 & 941 \\
\hline Educational Performance & 8.84 & 2.305 & 941 \\
\hline
\end{tabular}

Descriptive Statistics shows the "Mean" (103.29) and "Standard Deviation" is (11.249) of personality, Extracurricular Activities and Educational Performance.

\section{CORRELATiOnS}

\begin{tabular}{|c|c|c|c|c|}
\hline \multicolumn{2}{|r|}{ Table No. 7} & \multicolumn{3}{|c|}{ Correlations } \\
\hline & & Personality & $\begin{array}{c}\text { Extracurricular } \\
\text { Activities }\end{array}$ & Educational Performance \\
\hline \multirow{3}{*}{ Pearson Correlation } & Personality & 1.000 & .154 & .227 \\
\hline & Extracurricular Activities & .154 & 1.000 & .196 \\
\hline & Educational Performance & .227 & .196 & 1.000 \\
\hline \multirow{3}{*}{ Sig. (1-tailed) } & Personality & . & (2.000 & .000 \\
\hline & Extracurricular Activities & .000 & . & .000 \\
\hline & Educational Performance & .000 & .000 & . \\
\hline \multirow{3}{*}{$\mathrm{N}$} & Personality & 941 & 941 & 941 \\
\hline & Extracurricular Activities & 941 & 941 & 941 \\
\hline & Educational Performance & 941 & 941 & 941 \\
\hline
\end{tabular}

Here we've analyzed the bi variate (R) Pearson Correlation between "Personality with ECA's" is 0.154 , and between "Personality with Educational Performance is 0.227 ". Now Sig. (Significance 
level) "P" Value is 0.00 in all aspects, and it will always be less than 0.05 , so we found the very significant and positive relationship among D.V \& I.V, that shows that as much as students participate in ECA's in their Personality will develop and their academic performance will improve.

MODEL SUMMARY

\begin{tabular}{|c|c|c|c|c|c|}
\hline \multicolumn{3}{|c|}{ Table No. 8} & \multicolumn{3}{|c|}{ Model Summary } \\
\hline Model & $\mathrm{R}$ & R Square & Adjusted R Square & $\begin{array}{l}\text { Std. Error of the } \\
\text { Estimate }\end{array}$ & $\begin{array}{l}\text { Durbin- } \\
\text { Watson }\end{array}$ \\
\hline 1 & $.253^{\mathrm{a}}$ & .064 & .062 & 10.895 & 1.794 \\
\hline \multicolumn{6}{|c|}{ a. Predictors: (Constant), Educational Performance, Extracurricular Activities } \\
\hline \multicolumn{6}{|c|}{ b. Dependent Variable: Personality } \\
\hline
\end{tabular}

We've analyzed the bi variate correlation $\mathrm{r}(\mathrm{R})$ value is .253 and $\mathrm{R}^{2}$ is .064 , so its indicating that there is strong, significant \& positively correlated flanked by Personality (D.V) and Educational Performance \& Extracurricular Activities (I.V). However these values might be overestimated, so that we've took the "Adjusted R Square" for the better estimation of the values. "Std. Error of Estimation" is 10.895 . We also got the "Durbin-Watson" that's values are 1.794

ANOVA

\begin{tabular}{|c|c|c|c|c|c|c|}
\hline \multicolumn{3}{|c|}{ Table No. 9} & \multicolumn{4}{|c|}{ ANOVA $^{\mathrm{a}}$} \\
\hline \multicolumn{2}{|c|}{ Model } & Sum of Squares & Df & Mean Square & $\mathrm{F}$ & Sig. \\
\hline \multirow{3}{*}{1} & Regression & 7605.612 & 2 & 3802.806 & 32.034 & $.000^{\mathrm{b}}$ \\
\hline & Residual & 111351.765 & 938 & 118.712 & & \\
\hline & Total & 118957.377 & 940 & & & \\
\hline \multicolumn{7}{|c|}{ a. Dependent Variable: Personality } \\
\hline \multicolumn{7}{|c|}{ b. Predictors: (Constant), Educational Performance, Extracurricular Activities } \\
\hline
\end{tabular}

In above ANOVA results of Regression shows the relationship flanked by Personality (Big Fives)( D.V) and Educational Performance \& Extracurricular Activities (I.V). This table represents the values of "F Test" is 32.034 and as well as "Sig Value" is .000 that shows the considerable relation flanked by Personality (D.V) and Educational Performance \& Extracurricular Activities (I.V).

\section{COEFFICIENTS}

\begin{tabular}{|c|c|c|c|c|c|c|c|c|}
\hline \multicolumn{4}{|c|}{ Table No. 10} & \multicolumn{5}{|c|}{ Coefficients } \\
\hline & \multirow{2}{*}{ Model } & \multicolumn{2}{|c|}{$\begin{array}{l}\text { Un standardized } \\
\text { Coefficients }\end{array}$} & \multirow{2}{*}{$\begin{array}{c}\text { Standardized } \\
\text { Coefficients } \\
\text { Beta }\end{array}$} & \multirow[t]{2}{*}{$\mathrm{T}$} & \multirow[t]{2}{*}{ Sig. } & \multicolumn{2}{|c|}{$\begin{array}{l}95.0 \% \text { Confidence } \\
\text { Interval for B }\end{array}$} \\
\hline & & B & Std. Error & & & & $\begin{array}{l}\text { Lower } \\
\text { Bound } \\
\end{array}$ & $\begin{array}{l}\text { Upper } \\
\text { Bound } \\
\end{array}$ \\
\hline \multirow{3}{*}{1} & (Constant) & 92.015 & 1.470 & & 62.602 & .000 & 89.131 & 94.900 \\
\hline & Extracurricular Activities & .103 & .029 & .114 & 3.549 & .000 & .046 & .160 \\
\hline & Educational Performance & .996 & .157 & .204 & 6.337 & .000 & .688 & 1.305 \\
\hline
\end{tabular}

Standardized regression of coefficient always predicts the outcome of variables. As the above tables shows that the values of B, Std. Error, Beta, T-Test and Confidence Interval for B in both (Lower \& Upper) cases. If the values of the Sig are less than 0.05 then it shows that the "ECA's" \& "Personality Development" have significant results flanked by each other.

\section{RESIDUALS STATISTICS}

\begin{tabular}{|c|c|c|c|c|c|}
\hline \multicolumn{2}{|c|}{ Table No. 11 } & \multicolumn{4}{c|}{ Residuals Statistics } \\
\hline & Minimum & Maximum & Mean & Std. Deviation & $\mathrm{N}$ \\
\hline Predicted Value & 95.45 & 110.57 & 103.29 & 2.844 & 941 \\
\hline Residual & -49.386 & 25.079 & .000 & 10.884 & 941 \\
\hline Std. Predicted Value & -2.755 & 2.560 & .000 & 1.000 & 941 \\
\hline Std. Residual & -4.533 & 2.302 & .000 & .999 & 941 \\
\hline
\end{tabular}

It's a linear model of the residuals statistics that supports the random pattern. In both cases "Mean" and "Sum" of residuals are should be equal to "Zero". It represent $\Sigma e=0$ and $\mathrm{e}=0$. Here residual statistics are showing the data is appropriate; in other case noon linear residuals are also more suitable here in ECA's \& P.D. 


\section{FINDINGS}

Check the University student's response regarding ECA's and Personality. Hypothesis also express that ECA's develop the personality among university students. Cronbach's Alpha is 0.8 that retrospective the tremendous reliability of the questionnaire data. data collection from five universities of 941 students was a huge task. Students were belongs to Five different department (CS, Commerce/BA, Natural Sciences, Engineering, Arts and Others) An amazing thing was that among the 941 respondents (students) there were 352 (37.4\%) respondents were interested in Cricket, while only 66 (7\%) were interested in Hockey, rest of them were in other games. So I think Government of Pakistan should contemplate on the National game. There was strapping, positive and strong correlation " $\mathrm{r}$ " (R) and $\mathrm{R}^{2}$ values existed among Personality (D.V) and ECA's \& Educational Performance (I.V). Durbin-Watson (1.794) also advocating the significant findings among the whole values. Standardize Coefficient values, T-test scores; Sig values and Confidence Interval for B (Lower \& Upper Bond Values) are tremendously representing the significant findings.

\section{LiMITATIONS}

1. Personality model based on "Five Big" is enormously broad.

2. Respondent students perform in ECA's only in their leisure time.

3. Huge research required on this topic, but scarcity of funding \& time is hurdle.

4. This research study is narrow to personality \& ECA's \& Educational Performance.

5. Those students who are doing part time job, they don't participate in ECA's, but they've very shining personality.

\section{CONCLUSIONS AND RECOMMENDATIONS}

Prospective ECA's (thirteen types) always develop the multiple characteristics of the personality, as well as Educational achievement. Pupils of different universities got the confidence and learn how to plan the future among rival groups. Majority of students (male \& female) were interested in Cricket, then why still we're considering Hockey as our (Pakistan's) national game? So I think Government of Pakistan should contemplate on the National game. Meanwhile personality "Five Big" model was replicated from Norman (1963) that is enormously broad model. It'll explore many other horizons. If students' vigorously involve themselves in ECA's by sacrificing their study, automatically they'll lose their position in class.

\section{RECOMMENDATIONS}

\subsection{Recommendations for School Counselors}

1. Partnership of community always be encouraged.

2. Counselors should reciprocate the shy pupils individually.

3. Counselors should advocate students ECA's with academia.

4. Barriers should be removed from the participation in activities.

5. Counselors should avoid to practice of risky \& dangerous ECA's.

6. Skip the direct involvement of sponsors and politicians, in ECA's.

7. Over participation in activities could be perilous for the academia.

8. Encourage the pupils for ECA's, but also make their schedule for study.

9. Keep in mind the "Best fit" formula, for participation in activities and skills.

10. Students could be preventive the involvement from the risky extracurricular activities.

11. Best learning environment for extracurricular activities should be providing within the premises of university camps.

\subsection{Recommendations for Future Research}

1. In future diversity of ECA's will be discussed.

2. Pros \& cons of ECA's should be unveiled by all aspects.

3. How gender discrimination perform separately?

4. How disable students could be encouraged by community to participate in ECA's? 
5. Are all students availing equal opportunities in ECA's?

6. Only cross-sectional study is not enough, longitudinal research will explore the real picture.

7. Wider research required to find out the positive ways of win-win approach to motivate the students.

\section{REFERENCES}

[1] Armentrout, W.D. (1979). Neglected values in higher education: Needed reorganization in curricular and extra-curricular activities to provide significant experiences. Journal of Higher Education, 50: 361-367

[2] Battle, J., \& Lewis, M. (2002). The increasing significance of class: The relative effects of race and socioeconomic status on academic achievement. Journal of Poverty, 6(2), 21-35.

[3] Bloomfield, C. J., \& Barber, B. L. (2010). Australian adolescents' extracurricular activity participation and positive development: is the relationship mediated by peer attributes? . Australian Journal of Educational \& Developmental Psychology, 10, 114-128.

[4] Camp, W. (1990). Participation in student activities and achievement: A covariance structural analysis. Journal of Educational Research, 83: 272278.

[5] Darling, N., Caldwell, L. L., \& Smith, R. (2005). Participation in school-based extracurricular activities and adolescent adjustment. Journal of Leisure Research, 37(1), 51-76.

[6] Eberhardt, B.J., McGee, P., \& Moser, S. (1997). Business concerns regarding MBA education: Effects on recruiting. Journal of Education for Business, 72(5), 293-296

[7] Eccles, J., \& Midgley, C. (1990). Changes in academic motivation and self perceptions during early adolescents. In Montemayor, R. \& Adams, G.R.(Eds.), From Childhood to Adolescence: A Transitional Period? Advances in Adolescent Development: An Annual Book Series (Vol. 2). Sage, Thousand Oaks, CA, pp. 134-155.

[8] Farooq, M. S., Chaudhry, A. H., Shafiq, M., \& Berhanu, G. (2011). Factors affecting students' quality of academic performance: a case of secondary school level. Journal of quality and technology management, 7(2), 1-14.

[9] Fejgin, N. (1994). Participation in high school competitive sports: Subversion of school mission or contribution to academic goals? Sociology of Sport Journal, 11: 211230

[10] Finn J.D., \& Rock, D.A. (1997). Academic success among students at risk for school failure. Journal of Applied Psychology, 82: 221-234.

[11] Ford, D.Y. (1995). A Study of Achievement and Underachievement among Gifted, Potentially Gifted, and Average African-American Students. The National Research Center on the Gifted and Talented, University of Virginia, Charlottesville,VA. (ERIC Document Reproduction Service No. ED 429394.)

[12] Fung, Y. W., \& Wong, N. Y. (1988). Involvement in extracurricular activities as related to academic performance, personality, and peer acceptance.Methodology, 1987(1988).

[13] Gerber, S. (1996). Extracurricular activities and academic achievement. Journal of Research and Development in Education, 30: 4250.

[14] Gholson, R.E. (1985) Student achievement and co-curricular activity participation. NASSP Bulletin, 69: 17-20.

[15] Gordon, K.A. (1995). Self-concept and motivational patterns of African American high school students. Journal of Black Psychology, 21: 239-255.

[16] Gordon, K.A. (1996). Resilience and Motivation in Two Ethnic Minority Populations. (ERIC Document Reproduction Service No. ED404401).

[17] Hammer,D.P.(2000).Professional attitudes and behaviors: the" A's and B's" of professionnalism. American Journal of Pharmaceutical Education,64(4), 455-464.

[18] Heckman, J. J., \& Kautz, T. (2013). Fostering and measuring skills: Interventions that improve character and cognition (No. w19656). National Bureau of Economic Research.

[19] Holland, A., \& Andre, T. (1987). Participation in extracurricular activities in secondary school: What is known, what needs to be known? Review of Educational Research, 57: 437-66.

[20] Lewis, C. P. (2005). The relation between extracurricular activities with academic and social competencies in school age children: a meta-analysis (Doctoral dissertation, Texas A\&M University). 
[21] Mahoney, J. L., \& Cairns, R. B. (1997). Do extracurricular activities protect against early school dropout? Developmental Psychology, 33: 241-253.

[22] Marsh, H. (1991). Employment during high school: Character building or a subversion of academic goals? Sociology of Education, 64: 172-89.

[23] Marsh, H. (1992). Extracurricular activities: Beneficial extension of the traditional curriculum or subversion of academic goals? Journal of Educational Psychology, 84: 553562.

[24] Massoni, E. (2011). Positive Effects of Extra Curricular Activities on Students. ESSAI, 9(1), 27.

[25] McNeal, R. (1998). High school extracurricular activities: Closed structures and stratifying patterns of participation. Journal of Educational Research, 91: 183- 190.

[26] ODonnell, C.R. (1992). The interplay of theory and practice in delinquency prevention: From behavior modification to activity settings. In McCord, J. \& Tremblay, R.E. (Eds.), Preventing Antisocial Behavior: Interventions from Birth through Adolescence. Guilford, New York, pp. 209-232.

[27] Otto, L.B. (1976). Extracurricular activities and aspirations in the status attainment process. Rural Sociology, 41: 217-233.

[28] Park, D. (2015). The Range of Benefits of Extra-Curricular Activities towards English Language Learners.

[29] Pitts, S. E. (2008). Extra-curricular music in UK schools: investigating the aims, experiences and impact of adolescent musical participation. International Journal of Education \& the Arts, 9(10), $1-19$.

[30] Reis, S.M., Hebert, T.P., Diaz, E.I., Maxfield, L.R., \& Ratley, M.E. (1995). Case Studies of Talented Students who achieve and Underachieve in an Urban High School. National Research Center on the Gifted and Talented: Storrs, CT. (ERIC Document Reproduction Service No. ED414687.)

[31] Reva, A. (2012). The Role of Extracurricular Activities in Foreign Language Learning in University Settings.

[32] Reynolds, R.K., \& Karr-Kidwell, P.J. (1996). A Literary Review and a Plan for Principals: Extracurricular Activities, Academic Achievement, and Secondary Students Success. (ERIC Document Reproduction Service No. ED397475.)

[33] Silliker, S., \& Quirk, J. (1997). The effect of extracurricular activity participation on the academic performance of male and female high students. School Counselor, 44: 288293.

[34] Snyder, E.E., \& Spreitzer, E. (1992). Social psychological concomitants of adolescents role identities as scholars and athletes. Youth and Society, 23: 507-522.

[35] Soe, H. P. (2014). Perceptions of students and teachers on the role of extracurricular activities at a private university in Myanmar (Doctoral dissertation, Unitec Institute of Technology). Kolchenko, K., \& Kozlikovska, N. (2012). Development of Students'vocational Competence in the Frame of Extracurricular Activities. Social Welfare, 63.

[36] Spady, W.G. (1970). Lament for the letterman: Effects of peer status and extracurricular activities on goals and achievement. American Journal of Sociology, 75: 680- 702

[37] Steitz, J.A., \& Owen, T.P. (1992). School activities and work: Effects on adolescent self-esteem. Adolescence, 27: 37-50.

[38] Wangai, M. M. (2012). Determinants of the development of students talents in co-curricular activities in secondary schools in Mwatate district, Kenya (Doctoral dissertation, University of Nairobi, Kenya).

[39] Werner, E.E., \& Smith, R.S. (1982). Vulnerable but Invincible: A Longitudinal Study of Resilient Children and Youth. McGraw-Hill, New York, pp. 83-105.

[40] Wilson, N. (2009). Impact of extracurricular activities on students. University of WisconsinStout.

[41] Young, B.N., Helton, C., \& Whitley, M.E. (1997, November). Impact of School-Related, Community-Based, and Parental-Involvement Activities on Achievement of AtRisk Youth in the High School Setting. Paper presented at the Annual Meeting of the Mid-South Educational Research Association, Memphis, TN. (ERIC Document Reproduction Service No. ED414533.) 